\title{
PENGARUH LINGKUNGAN KELUARGA, KEDISIPLINAN SISWA, DAN MOTIVASI BELAJAR TERHADAP HASIL BELAJAR EKONOMI SISWA DI SMA NEGERI 7 SURABAYA
}

\author{
Umi Chulsum, SMP Negeri 12 Surabaya \\ u.chulsum@yahoo.co.id
}

\begin{abstract}
ABSTRAK
Penelitian ini bertujuan untuk : menganalisis pengaruh lingkungan keluarga terhadap hasil belajar ekonomi siswa di SMA Negeri 7 Surabaya, menganalisis pengaruh kedisiplinan siswa terhadap hasil belajar ekonomi siswa di SMA Negeri 7 Surabaya, menganalisis pengaruh motivasi belajar terhadap hasil belajar ekonomi siswa di SMA Negeri 7 Surabaya, dan menganalisis pengaruh lingkungan keluarga, kedisiplinan siswa dan motivasi belajar secara bersama-sama berpengaruh terhadap hasil belajar ekonomi siswa di SMA Negeri 7 Surabaya. Penelitian ini merupakan penelitian kuantitatif. Populasi dalam penelitian ini adalah siswa kelas X dan kelas XI IPS SMA Negeri 7 Surabaya tahun pelajaran 2014 - 2015 sebanyak 228 orang, sedangkan jumlah sampel yang digunakan sebanyak 145 orang. Adapun teknik pengumpulan data yang digunakan yaitu angket, wawancara, dan dokumentasi. Metode analisis menggunakan Teknik Regresi Linier Berganda. Hasil penelitian menunjukkan bahwa : ada pengaruh yang signifikan dan positif antara lingkungan keluarga terhadap hasil belajar ekonomi siswa SMA Negeri 7 Surabaya, ada pengaruh yang signifikan dan positif antara kedisiplinan siswa terhadap hasil belajar ekonomi siswa SMA Negeri 7 Surabaya, ada pengaruh yang signifikan dan positif antara motivasi belajar terhadap hasil belajar ekonomi siswa SMA Negeri 7 Surabaya, dan ada pengaruh yang signifikan dan positif antara lingkungan keluarga, kedisiplinan siswa dan motivasi belajar terhadap hasil belajar ekonomi siswa SMA Negeri 7 Surabaya.

Kata Kunci: Lingkungan Keluarga, Kedisiplinan Siswa, Motivasi Belajar, Hasil Belajar
\end{abstract}

\begin{abstract}
This study aims to: analyze the influence of family environment on learning outcomes at economics lesson of students in high school economics Negeri 7 Surabaya, analyze the influence of students dicipline on learning outcomes in economics lesson of student at SMAN 7 Surabaya, analyze the influence of learning motivation on learning outcomes in economics lesson of student at SMAN 7 Surabaya, and also the impact of family environment, students dicipline and learning motivation at the same time on the learning outcomes on economics lesson of student at SMAN 7 Surabaya. This research is quantitative. The population in this research were students of class $X$ and class XI IPS at SMA Negeri 7 Surabaya year 2014-2015 as many as 228 students, while the number of samples used as
\end{abstract}


much as 145 students. The data collection techniques that used are questionnaires, interviews, and documentation. Methods of analysis using multiple linear regression techniques. The results showed that: there is a significant and positive effect between family environment on learning outcomes in economics lesson of student at SMAN 7 Surabaya, a significant and positive effect between students dicipline on learning outcomes in economics lesson of student at SMAN 7 Surabaya, a significant and positive effect between learning motivation on learning outcomes in economics lesson of student at SMAN 7 Surabaya, and a significant and positive relations between family environment, student discipline and learning motivation jointly toward learning outcomes on economics lesson of students at SMAN 7 Surabaya.

Keywords: Family Environment, Student Discipline, Learning Motivation, Learning Outcomes

\section{PENDAHULUAN}

Pendidikan merupakan salah satu komponen yang sangat berperan dalam menentukan nasib suatu bangsa. Keberhasilan dalam bidang pendidikan terus diupayakan oleh pemerintah karena pendidikan merupakan pondasi yang kuat bagi perkembangan negara tersebut. Keberhasilan pendidikan sangat dipengaruhi oleh perubahan dan pembaharuan dalam segala unsur-unsur yang mendukung pendidikan diantaranya siswa, guru, alat dan metode, materi serta lingkungan pendidikan. Semua unsur tersebut saling terkait antara satu dengan lainnya dalam mendukung tercapainya tujuan pendidikan.

Tujuan pendidikan dapat dilihat dari keberhasilan proses belajar yang dapat diukur melalui hasil belajar. Menurut Theresia (2011) hasil belajar adalah hasil yang diperoleh melalui sebuah kegiatan belajar mata pelajaran tertentu secara mandiri untuk mengetahui seberapa jauh tujuan pembelajaran telah tercapai. Hasil belajar materi ekonomi adalah hasil yang diperoleh melalui sebuah kegiatan belajar materi ekonomi secara mandiri untuk mengetahui seberapa jauh tujuan pembelajaran telah tercapai. Dalam kenyataannya tidak mudah bagi siswa memperoleh hasil belajar materi ekonomi yang memuaskan seperti yang diharapkan

Hasil belajar materi ekonomi siswa di SMA Negeri 7 masih di bawah standar nilai KKM. Hal ini dapat dilihat dari hasil ulangan harian siswa yang menunjukkan bahwa masih ada sekitar 30\% dari keseluruhan siswa yang nilai ulangan harian belum memenuhi standar ketuntasan yang ditetapkan sekolah yaitu nilai 75 , sehingga siswa-siswa tersebut masih harus mengikuti ulangan perbaikan atau remidial.

Pencapaian hasil belajar oleh siswa tersebut tidak terlepas dari faktorfaktor yang mempengaruhi belajar itu sendiri. Berdasarkan faktor-faktor yang mempengaruhi tersebut perlu diketahui dan diteliti. Faktor yang menentukan keberhasilan pembelajaran siswa dipengaruhi oleh dua faktor yang meliputi faktor internal dan faktor eksternal.

Salah satu faktor dari luar diri siswa yang dapat mendorong siswa untuk meraih hasil belajar adalah lingkungan keluarga. Hasbullah (2010) Keluarga merupakan lembaga pendidikan tertua, yang pertama dan utama dialami oleh 
anak. Kedudukannya sebagai lembaga pendidikan yang bersifat kodrati menjadikan peranan orang tua memiliki peranan untuk bertanggung jawab memelihara, merawat, melindungi dan mendidik anak agar bisa tumbuh dan berkembang dengan baik.

Menurut Khafid dan Suroso (2007) di dalam keluarga seorang anak mengalami proses sosialisasi untuk pertama kalinya dimana dalam proses ini seorang anak diajarkan dan dikenalkan berbagai nilai kehidupan yang sangat berguna dan menentukan bagi perkembangan anak dimasa depan. Semakin baik lingkungan keluarga dalam mendidik dan menerapkan pembelajaran di rumah akan memunculkan sikap kedisiplinan siswa dalam belajar maka akan semakin baik juga hasil belajar yang diperoleh seorang anak.

Di SMA Negeri 7 Surabaya, hampir $60 \%$ kedua orang tua mereka bekerja, sehingga mereka cenderung menyerahkan proses pembelajaran siswa sepenuhnya kepada sekolah. Kesibukan orang tua siswa terhadap pekerjaannya menyebabkan kurangnya perhatian yang mereka berikan pada siswa, sehingga sebagian dari orang tua memilih anak-anak mereka untuk les privat atau mengikuti bimbingan belajar selain mendapatkan pembelajaran di sekolah.

Faktor lain yang juga berpengaruh terhadap hasil belajar siswa adalah disiplin. Disiplin siswa menurut Yudhawati dan Dany (2011) berarti kepatuhan dan ketaatan siswa terhadap berbagai aturan dan tata tertib yang berlaku disekolahnya. Disiplin merupakan kesediaan untuk memenuhi peraturanperaturan dan larangan-larangan. Kepatuhan disini bukan hanya patuh karena adanya tekanan-tekanan dari luar melainkan kepatuhan yang didasari oleh adanya kesadaran tentang nilai dan pentingnya peraturan-peraturan dan larangan-larangan tersebut.

Kedisiplinan harus dijalankan dengan konsisten, teratur dan jelas sesuai dengan peraturan tata tertib yang telah ditetapkan, sehingga siswa akan terbiasa hidup teratur. Dengan adanya tata tertib siswa maka setiap tindakan dan perilaku siswa akan dikontrol, sehingga kedisiplinan siswa disekolah dapat tercipta. Didukung dengan penelitian Pasternak (2013) yang menunjukkan bahwa variabel disiplin mempunyai korelasi positif dan signifikan terhadap prestasi akademik. Penanganan masalah ketidakdisplinan yang terjadi memberi dampak positif pada hasil belajar siswa.

Menurut Ismani (2012) kedisiplinan yang tinggi dapat disebabkan oleh adanya sikap disiplin siswa dalam hal tata tertib sekolah, taat terhadap kegiatan belajar disekolah, taat dalam mengerjakan tugas-tugas pelajaran dan taat dalam belajar dirumah. Menurut Sukawijaya (2010) terdapat kontribusi yang positif dan signifikan antara kedisiplinan diri terhadap hasil belajar sehingga semakin baik kedisiplinan siswa maka semakin baik pula hasil yang diraih.

Fenomena yang terjadi pada siswa di SMA Negeri 7 Surabaya diantaranya masih ditemuinya siswa yang kurang disiplin, pelanggaran yang sering dilakukan siswa diantaranya meliputi terlambat datang ke sekolah, seragam yang tidak lengkap, menyontek ketika ulangan, tidak mengerjakan tugas, tidur pada saat KBM, dan siswa yang ramai saat mengikuti pelajaran. Untuk menciptakan kedisiplinan siswa di sekolah, SMA Negeri 7 Surabaya menetapkan peraturan siswa. Dalam tata tertib tersebut diatur segala kewajiban siswa, larangan siswa, dan sanksi yang akan diterima siswa. Ketidakdisiplinan 
di sekolah akan mengakibatkan motivasi belajar, keseriusan belajar dan daya serap siswa menjadi kurang.

Faktor lain yang berpengaruh pada hasil belajar siswa adalah motivasi. Motivasi adalah dorongan yang menyebabkan terjadinya suatu perbuatan atau tindakan. Proses belajar pada siswa terjadi karena adanya motivasi untuk melakukan suatu kegiatan belajar. Motivasi belajar penting peranannya bagi siswa dalam usaha mencapai prestasi belajar yang tinggi. Siswa yang memiliki motivasi belajar yang tinggi, cenderung menunjukkan semangat dan kegairahan dalam mengikuti pelajaran, mereka biasanya kelihatan lebih menaruh perhatian bersungguh-sungguh dalam belajar dan aktif berpartisipasi dalam kegiatan pembelajaran, baik di kelas maupun di luar kelas.

Menurut Uno (2008), motivasi adalah dorongan internal dan eksternal dalam diri seseorang untuk mengadakan perubahan tingkah laku. Motivasi adalah suatu keadaan dalam diri individu yang menyebabkan seseorang melakukan kegiatan tertentu untuk mencapai tujuan (Hamalik, 2011).

Motivasi belajar yang tinggi akan mempengaruhi hasil belajar siswa, karena itu siswa akan berusaha untuk mencoba mengerjakan soal-soal latihan terhadap materi pelajaran yang telah diberikan oleh guru. Sebaliknya, seorang siswa yang tidak memiliki motivasi dalam dirinya, kecil kemungkinan ia akan dapat berprestasi baik. Hal ini didukung oleh penelitian yang dilakukan Purnomowati (2006) bahwa variabel motivasi belajar berpengaruh secara signifikan terhadap prestasi akademik siswa. Hasil penelitian dari Nur Fadillah (2011) menyatakan bahwa variabel motivasi belajar memberikan pengaruh yang signifikan terhadap prestasi belajar mata diklat menangani surat masuk dan keluar siswa.

Permasalahan yang dihadapi di SMA Negeri 7 Surabaya adalah rendahnya rasa keingintahuan dalam mempelajari pelajaran ekonomi, siswa termotivasi untuk mengerjakan tugas hanya karena mereka ingin menerima pujian dari guru dan terhindar dari hukuman. Rendahnya motivasi juga dapat dilihat pada saat proses belajar mengajar dimana masih ada siswa yang tidak memperhatikan, tidak bergairah menerima pelajaran dan asyik dengan aktivitasnya sendiri, oleh karena itu tidak mengherankan jika siswa tersebut nilai prestasi belajarnya rendah, sehingga dalam pencapaian nilai ketuntasan minimum harus melakukan remidi.

\section{METODE PENELITIAN}

Pendekatan yang digunakan dalam penelitian ini adalah pendekatan kuantitatif. Penelitian ini merupakan penelitian tingkat eksplanasi (level explanation). Menurut David Kline (dalam Sugiyono, 2011) "Tingkat eksplanasi adalah tingkat penjelasan" jadi penelitian ini adalah penelitian yang menjelaskan kedudukan variabel-variabel yang diteliti serta pengaruh antara satu variabel dengan variabel lain. Variabel yang digunakan pada penelitian ini adalah hasil belajar $(\mathrm{Y})$, serta lingkungan keluarga $\left(\mathrm{X}_{1}\right)$, kedisiplinan siswa $\left(\mathrm{X}_{2}\right)$, dan motivasi belajar $\left(\mathrm{X}_{3}\right)$.

Populasi dalam penelitian ini adalah siswa kelas X dan kelas XI jurusan IPS SMA Negeri 7 Surabaya semester genap tahun pelajaran 2014-2015 sebanyak 228 siswa. Sampel penelitian sebanyak 145 siswa ditetapkan dengan 
teknik Propotional Random. Propotional Random Sampling yaitu teknik pengambilan anggota sampel bila populasi mempunyai anggota atau unsur yang tidak homogen secara proposional (Sugiyono, 2011).

Data dikumpulkan menggunakan angket (kuesioner) dan dokumentasi. Dokumentasi digunakan untuk mengumpulkan data dari variabel hasil belajar dengan menggunakan nilai Ulangan Tengah Semester (UTS). Sedangkan kuesioner digunakan untuk mengumpulkan data dari variabel lingkungan keluarga, kedisiplinan siswa, dan motivasi belajar. Kuesioner disusun berdasarkan variabel penelitian dan indikator penelitian dengan menggunakan skala likert. Berikut adalah indikator dari variabel lingkungan keluarga, kedisiplinan siswa, dan motivasi belajar.

1. Indikator lingkungan keluarga terdiri dari :

a. Sikap positif orang tua

b. Persepsi orang tua terhadap keberhasilan

c. Dukungan Orang Tua

Sumber : Patricia Robledo-Ramón and Jesús-Nicasio García-Sánchez (2012)

2. Indikator kedisiplinan siswa terdiri dari :

a. Menaati dan mematuhi tata tertib sekolah

b. Masuk kelas tepat waktu

c. Ketertiban diri saat belajar di kelas

d. Mengatur waktu belajar di rumah

e. Mengulang kembali pelajaran di rumah

f. Mengerjakan tugas sekolah di rumah

Sumber : Djamarah (2011), Tu`u (2004)

3. Indikator motivasi belajar terdiri dari :

a. Keinginan untuk berprestasi

b. Harapan untuk berhasil

c. Belajar dari kegagalan/ ketidakberdayaan

Sumber : Tella (2007)

Teknik analisis menggunakan analisis uji statistik $\mathrm{t}$ dan uji $\mathrm{F}$. Uji $\mathrm{t}$ digunakan untuk menguji signifikansi pengaruh lingkungan keluarga terhadap hasil belajar ekonomi, pengaruh kedisiplinan siswa terhadap hasil belajar ekonomi, dan pengaruh motivasi belajar terhadap hasil belajar ekonomi. Uji $\mathrm{F}$ digunakan untuk menguji signifikansi pengaruh variabel lingkungan keluarga, kedisiplinan siswa, dan motivasi belajar terhadap hasil belajar ekonomi.

\section{HASIL PENELITIAN DAN PEMBAHASAN}

Model regresi yang diperoleh berdasarkan hasil penelitian, dapat dituliskan dalam bentuk persamaan regresi sebagai berikut : $\mathrm{HB}(\mathrm{Y})=68,596+$ $0,497 \mathrm{LK}\left(\mathrm{X}_{1}\right)+0,428 \mathrm{KS}\left(\mathrm{X}_{2}\right)+0,658 \mathrm{MB}\left(\mathrm{X}_{3}\right)+\mathrm{e}_{\mathrm{i}}$. Dari persamaan regresi tersebut ketiga variabel bebas memiliki koefisien regresi dengan arah positif. Hal ini berarti semakin baik lingkungan keluarga, kedisiplinan siswa dan motivasi belajar akan meningkatkan hasil belajar. Hasil uji $\mathrm{F}$ menunjukkan bahwa nilai Fhitung yang dihasilkan sebesar 5,789 dengan nilai signifikan 0,001 kurang dari dari 0,05. Hal ini berarti lingkungan keluarga, kedisiplinan siswa, dan motivasi belajar secara simultan berpengaruh terhadap hasil belajar siswa. 
Koefisien determinasi (R-square) yang dihasilkan dalam penelitian ini sebesar 0,110 menunjukkan bahwa hasil belajar siswa dipengaruhi oleh lingkungan keluarga, kedisiplinan siswa dan motivasi belajar sebesar 11\% sedangkan $89 \%$ dipengaruhi oleh faktor-faktor lain selain variabel dalam penelitian.

Hasil uji t menunjukkan bahwa semua variabel mempunyai pengaruh yang signifikan. Nilai t hitung pada variabel lingkungan keluarga $\left(\mathrm{X}_{1}\right)$ sebesar 2,239 lebih besar dari t tabel 1,66 dan nilai signifikansi 0,027 lebih kecil dari 0,05 . Nilai t hitung pada variabel kedisiplinan siswa $\left(\mathrm{X}_{2}\right)$ sebesar 2,436 lebih besar dari t tabel 1,66 dan nilai signifikansi 0,016 lebih kecil dari 0,05. Nilai t hitung pada variabel motivasi belajar $\left(\mathrm{X}_{3}\right)$ sebesar 2,617 lebih besar dari t tabel 1,66 dan nilai signifikansi 0,010 lebih kecil dari 0,05 . Dengan tingkat signifikan yang kurang dari 5\% maka lingkungan keluarga, kedisiplinan siswa dan motivasi belajar secara parsial berpengaruh signifikan terhadap hasil belajar (Y).

\section{Pengaruh Lingkungan Keluarga Terhadap Hasil Belajar Ekonomi}

Berdasarkan hasil analisis menunjukkan bahwa lingkungan keluarga berpengaruh signifikan dan positif pada hasil belajar siswa. Hasil tersebut mempunyai makna bahwa semakin baik lingkungan keluarga siswa maka hasil belajar siswa juga semakin baik.

Adapun kriteria yang digunakan untuk penilaian setiap variabel adalah : Sangat rendah $(1,00-1,80)$, Rendah $(1,81-2,60)$, cukup $(2,61-3,40)$, tinggi $(3,41-4,20)$, dan sangat tinggi $(4,21-5,00)$.

Lingkungan keluarga siswa kelas X dan IX IPS SMA Negeri 7 Surabaya berdasarkan jawaban responden pada rekapitulasi distribusi frekuensi variabel lingkungan keluarga diperoleh nilai rata-rata variabel lingkungan keluarga sebesar 4,50 termasuk kategori sangat tinggi, dimana nilai rata-rata indikator sikap positif orang tua sebesar 4,42 termasuk kategori sangat tinggi, nilai ratarata indikator persepsi orang tua terhadap keberhasilan siswa sebesar 4,60 termasuk kategori sangat tinggi, dan nilai rata-rata indikator dukungan orang tua sebesar 4,49 termasuk kategori sangat tinggi.

Hal ini berarti bahwa kepedulian dan perhatian yang tinggi dari orang tua terhadap pendidikan anaknya, membiasakan anaknya belajar dengan penuh kosentrasi yaitu dengan mengkondisikan suasana yang tenang dan nyaman dalam belajar maka hasil belajar siswa akan semakin baik.

Berdasarkan koefisien regresi pada variabel lingkungan keluarga adalah positif, nilai positif pada variabel lingkungan keluarga memiliki hubungan yang searah dengan hasil belajar siswa yaitu semakin baik lingkungan keluarga siswa maka akan semakin tinggi hasil belajar siswa.

Temuan ini menunjukkan bahwa lingkungan keluarga berpengaruh untuk meningkatkan hasil belajar siswa sesuai dengan pengertian lingkungan keluarga menurut Achmad Munib (2005) yaitu lingkungan yang pertama dan utama, karena sebelum manusia mengenal lembaga pendidikan yang lain, lembaga inilah yang pertama ada. Pola pendidikan orang tua yang baik dan suasana keluarga yang harmonis, menjadikan keadaan psikologis anak terkontrol. Hal ini akan mendukung proses belajar anak akan berjalan lancar, 
tenang, bersemangat, untuk belajar dan anak akan merasa diperhatikan dan juga termotivasi untuk belajar.

Slameto (2010) juga menyatakan bahwa faktor keluarga memainkan peranan yang cukup penting dalam penyesuaian diri siswa dan hasil belajar. Djaali (2013) menjelaskan bahwa lingkungan keluarga merupakan situasi keluarga yang terdiri dari Ayah, Ibu, Saudara, Adik, Kakak serta famili yang akan berpengaruh terhadap keberhasilan anak dalam keluarga.

Hasil tersebut sesuai dengan penelitian yang dilakukan Mohanraj (2005) yang menyatakan bahwa antara lingkungan keluarga dan prestasi akademik berkorelasi dan berhubungan positif serta signifikan. Codjoe and Dalton (2007), Mackay (2005), dan Abolarin (2014) yang menyatakan bahwa antara lingkungan keluarga berpengaruh signifikan terhadap hasil belajar.

Dari hasil analisis data, telah terbukti jika ada pengaruh yang signifikan dan positif antara lingkungan keluarga dengan hasil belajar siswa di SMA Negeri 7 Surabaya. Jika lingkungan keluarga baik maka hasil belajar yang didapat juga akan tinggi, dan sebaliknya jika lingkungan keluarga kurang mendukung maka hasil belajar yang didapatkan juga rendah. Hal ini sesuai dengan teori dan penelitian-penelitian terdahulu.

\section{Pengaruh Kedisiplinan Siswa Terhadap Hasil Belajar Ekonomi}

Berdasarkan hasil analisis menunjukkan bahwa kedisiplinan siswa berpengaruh signifikan dan positif pada hasil belajar siswa. Hasil tersebut mempunyai makna bahwa semakin tinggi kedisiplinan siswa maka semakin tinggi hasil belajar ekonomi siswa di SMA Negeri 7 Surabaya

Kedisiplinan siswa kelas $\mathrm{X}$ dan IX IPS SMA Negeri 7 Surabaya berdasarkan jawaban responden pada rekapitulasi distribusi frekuensi variabel kedisiplinan siswa diperoleh nilai rata-rata variabel kedisiplinan siswa sebesar 3,94 termasuk kategori tinggi, dimana nilai rata-rata indikator menaati dan mematuhi tata tertib sekolah yaitu sebesar 3,76 termasuk kategori tinggi, nilai rata-rata indikator masuk kelas tepat waktu yaitu sebesar 3,93 termasuk kategori tinggi, nilai rata-rata indikator ketertiban diri saat belajar di kelas yaitu sebesar 3,91 termasuk kategori tinggi, nilai rata-rata indikator mengatur waktu belajar di rumah yaitu sebesar 3,91 termasuk kategori tinggi, nilai rata-rata indikator mengulang kembali pelajaran di rumah yaitu sebesar 3,98 termasuk kategori tinggi, dan nilai rata-rata indikator mengerjakan tugas sekolah di rumah yaitu sebesar 4,18 termasuk kategori tinggi.

Hal ini berarti bahwa siswa kelas X dan IX IPS SMA Negeri 7 Surabaya memiliki kedisiplinan tinggi, hal tersebut bisa kita buktikan dari sikap siswa yang selalu mematuhi tata tertib sekolah, tidak lagi terlambat masuk sekolah, tidak ada lagi siswa yang malas atau menunda menyelesaikan pekerjaan maupun tugas yang diberikan guru, siswa selalu membiasakan belajar secara teratur di rumah, siswa selalu mempelajari materi pelajaran di rumah serta berusaha mencoba untuk mengerjakan soal-soal yang berkaitan dengan materi yang telah diajarkan di sekolah, dan siswa yang selalu berusaha keras untuk mengerjakan dan menyelesaikan PR maupun tugas dari guru dengan penuh semangat. Sehingga dengan kedisiplinan siswa yang tinggi maka hasil belajar siswa juga tinggi. 
Berdasarkan koefisien regresi pada variabel kedisiplinan siswa adalah positif, nilai positif pada variabel kedisiplinan siswa memiliki hubungan yang searah dengan hasil belajar siswa yaitu semakin tinggi kedisiplinan siswa maka akan semakin tinggi hasil belajar siswa.

Temuan ini menunjukkan bahwa kedisiplinan siswa berpengaruh untuk meningkatkan hasil belajar siswa sesuai dengan pengertian disiplin menurut Moenir (2010) yaitu suatu bentuk ketaatan terhadap aturan baik tertulis maupun tidak tertulis yang telah ditetapkan. Kedisiplinan siswa merupakan kesesuaian antara sikap, tingkah laku dan perbuatan siswa dengan suatu peraturan yang sedang diberlakukan disekolah. Guna mewujudkan disiplin dalam diri siswa diperlukan adanya peraturan atau tata tertib dalam kegiatan belajar mengajar di sekolah. Dengan adanya peraturan tersebut setiap sikap tindakan yang mencerminkan kedisiplinan akan dilaksanakan dengan baik dan benar. Kedisiplinan muncul terutama karena adanya kesadaran batin dan iman kepercayaan bahwa yang dilakukan itu baik dan bermanfaat bagi diri sendiri dan lingkungan. Dengan disiplin para siswa bersedia untuk tunduk dan mengikuti peraturan tertentu dan menjauhi larangan tersebut.

Menurut Tomo (2008) menyatakan dengan dikembangkannya disiplin belajar pada siswa maka siswa dapat mengembangkan motivasi pada dirinya agar dapat belajar dengan lebih giat dan teratur yang pada akhirnya dapat meningkatkan prestasi belajarnya di sekolah. Lebih lanjut dikatakan bahwa salah satu hal yang menyebabkan tinggi rendahnya prestasi belajar adalah keteraturan dan disiplin dalam belajar itu sendiri. Bentuk disiplin yang paling baik adalah yang bersifat sadar karena adanya kesadaran dalam diri seseorang maka akan menjadi pendorong dalam dirinya untuk berperilaku sesuai dengan nilai-nilai yang berlaku. Dan dari hasil penelitiannya dengan judul hubungan antara sikap, motivasi dan disiplin belajar dan prestasi belajar mahasiswa D-II PGSD prajabatan FKIP Universitas Pattimura menunjukkan jika variabel disiplin belajar berada pada kategori tinggi, dimana terdapat hubungan yang positif dan signifikan baik secara parsial dan simultan terhadap prestasi belajar.

Hasil tersebut sesuai dengan penelitian yang dilakukan oleh Setyowati (dalam Tomo, 2008) menyatakan belajar harus disiplin, karena disiplin adalah kunci sukses. Diungkapkan pula untuk mencapai hasil belajar maksimal diperlukan sikap mental siswa dalam mengarahkan seluruh kegiatan belajarnya. Siswa yang ingin hasil belajarnya tinggi harus mempunyai disiplin belajar yang tinggi. Hal ini disebabkan karena disiplin yang tinggi membuat siswa senantiasa mempunyai kesediaan, kegairahan dan tanggung jawab dalam belajar. Tanpa sikap ini, siswa cenderung tidak mampu mengatasi berbagai hambatan dan kesulitan dalam belajar.

Hal ini sejalan dengan penelitian yang dilakukan oleh Sukawijaya (2010) yang berjudul Kontribusi hasil belajar seni rupa, kedisiplinan diri dan motivasi berprestasi terhadap hasil belajar komputer grafis siswa program keahlian multimedia SMK Negeri 2 Sukawati, yang menyimpulkan bahwa kedisiplinan berpengaruh positif dan signifikan terhadap hasil belajar.

Penelitian yang juga mendukung adalah penelitian yang dilakukan oleh Pasternak (2013), Chou Pao (2012), dan Lawrence (2012) yang menyatakan bahwa terdapat pengaruh yang signifikan antara kedisiplinan belajar terhadap hasil akademik siswa. 
Dari hasil analisis data, telah terbukti jika ada pengaruh yang signifikan dan positif antara kedisiplinan siswa dengan hasil belajar siswa di SMA Negeri 7 Surabaya. Dapat dikatakan jika kedisiplinan siswa tinggi maka hasil belajar yang didapat juga akan tinggi, dan sebaliknya jika kedisiplinan siswa rendah maka hasil belajar yang didapat juga rendah.

\section{Pengaruh Motivasi Belajar Terhadap Hasil Belajar Ekonomi}

Berdasarkan hasil analisis menunjukkan bahwa motivasi belajar berpengaruh signifikan dan positif pada hasil belajar siswa. Hasil tersebut mempunyai makna bahwa motivasi siswa akan meningkat apabila hasil belajar siswa ditingkatkan. Semakin tinggi motivasi siswa, semakin baik pula hasil belajar siswa di SMA Negeri 7 Surabaya.

Motivasi belajar siswa kelas X dan IX IPS SMA Negeri 7 Surabaya berdasarkan jawaban responden pada rekapitulasi distribusi frekuensi variabel motivasi belajar diperoleh nilai rata-rata variabel motivasi belajar sebesar 4,39 termasuk kategori sangat tinggi. Nilai rata-rata indikator keinginan untuk berprestasi yaitu sebesar 4,34 termasuk kategori sangat tinggi, nilai rata-rata indikator harapan untuk berhasil yaitu sebesar 4,43 termasuk kategori sangat tinggi, dan nilai rata-rata indikator belajar dari kegagalan/ ketidakberdayaan yaitu sebesar 4,41 termasuk kategori sangat tinggi.

Tingginya motivasi belajar siswa dikarenakan keinginan siswa dalam mencapai prestasi yang tinggi sehingga mereka menjadi lebih tekun dan giat belajar untuk mencapai keinginan tersebut. Selain itu adanya harapan untuk berhasil yang sangat tinggi dan kemauan siswa untuk belajar dari kegagalan/ ketidakberdayaan yang sangat tinggi pula, sehingga siswa berusaha keras untuk mendapatkan nilai yang baik di skolah. Dengan demikian semakin tinggi motivasi belajar siswa maka semakin tinggi pula hasil belajar yang akan diperoleh.

Berdasarkan koefisien regresi pada variabel motivasi belajar adalah positif, nilai positif pada variabel motivasi belajar memiliki hubungan yang searah dengan hasil belajar siswa yaitu semakin tinggi motivasi belajar maka akan semakin tinggi hasil belajar siswa.

Hasil penelitian ini mendukung teori-teori yang telah diungkapkan antara lain oleh Uno (2008) yang mengungkapkan bahwa dalam proses pembelajaran motivasi memiliki peranan penting untuk memperoleh hasil belajar yang baik, karena apabila seorang siswa yang telah termotivasi untuk belajar sesuatu, maka ia akan berusaha mempelajarinya dengan baik dan tekun, dengan harapan memperoleh hasil yang memuaskan. Hal yang sama juga diungkapkan oleh Djamarah (2011) yang menyatakan bahwa dalam proses belajar, motivasi belajar sangat diperlukan sebab seorang yang tidak mempunyai motivasi dalam belajar tidak akan mungkin melakukan aktivitas belajar. Sehingga dengan aktivitas belajar maka akan mempengaruhi hasil belajar.

Dalam penelitian Tella (2007) yang menyatakan bahwa di sekolah menengah terdapat perbedaan secara signifikan dalam prestasi akademik mereka berdasarkan sejauh mana mereka termotivasi, dan mengungkapkan bahwa siswa yang sangat termotivasi tampil lebih baik dalam hal akademis daripada siswa yang memiliki motivasi rendah. 
Motivasi mempunyai peranan penting dalam kegiatan belajar, dimana motivasi menjadi tenaga yang menggerakkan dan mengarahkan aktivitas seseorang. Motivasi mempunyai kaitan yang erat dengan minat. Siswa yang memiliki minat terhadap sesuatu bidang studi tertentu cenderung tertarik perhatiannya den dengan demikian timbul motivasi untuk mempelajarinya.

Hal ini sesuai dengan penelitian Andartari dkk (2013), Awan dkk (2011), Tomo (2008), Mappeasse (2009), dan Nur Fadillah (2011) yang menunjukkan bahwa motivasi belajar berhubungan positif dan berpengaruh positif terhadap hasil belajar.

Dari hasil penjelasan di atas dapat diketahui jika siswa memiliki motivasi belajar tinggi maka akan meningkatkan hasil belajar mereka. Hal ini terjadi karena saat siswa mempunyai motivasi yang tinggi maka siswa akan mempunyai minat dan semangat yang tinggi pula saat belajar. Saat semangat dan minat tinggi inilah mereka mempunyai perhatian lebih terhadap pelajaran tersebut sehingga meningkatlah hasil belajar mereka. Dan sebaliknya jika siswa tidak mempunyai motivasi belajar maka minat dan semangat mereka juga rendah sehingga akan membuat sisewa malas untuk memperhatikan materimateri pembelajaran yang diberikan oleh guru. Cepat atau lambat itu juga akan mempengaruhi hasil belajar mereka menjadi semakin menurun dan rendah.

Dari hasil analisis data, telah terbukti jika ada pengaruh yang signifikan dan positif antara motivasi belajar dengan hasil belajar siswa di SMA Negeri 7 Surabaya. Dapat dikatakan jika motivasi belajar tinggi maka hasil belajar yang didapat juga akan tinggi, dan sebaliknya jika motivasi belajar rendah maka hasil belajar yang didapatkan juga rendah.

\section{Pengaruh lingkungan keluarga, kedisiplinan dan motivasi belajar terhadap hasil belajar ekonomi}

Dalam penelitian ini diperoleh hasil bahwa lingkungan keluarga, kedisiplinan siswa, motivasi belajar secara simultan berpengaruh signifikan dan positif terhadap hasil belajar ekonomi di SMA Negeri 7 Surabaya. Hasil tersebut mempunyai makna bahwa lingkungan keluarga, kedisiplinan siswa dan motivasi belajar secara bersama-sama berpengaruh terhadap hasil belajar. Lingkungan keluarga yang baik dan kedisiplinan yang tinggi serta motivasi belajar yang tinggi maka hasil belajar yang dicapai siswa akan tinggi.

Berdasarkan hasil koefisien determinasi menunjukkan bahwa pengaruh lingkungan keluarga, kedisiplinan siswa dan motivasi belajar terhadap hasil belajar sangat kecil, hal tersebut dikarenakan adanya pengaruh dari variabel lain yang tidak dibahas dalam penelitian ini.

Pada variabel lingkungan keluarga, indikator sikap positif orang tua nilai rata-rata sebesar 4,42 masuk dalam kategori sangat tinggi, hal ini berarti orang tua siswa kelas X dan XI IPS SMA Negeri 7 Surabaya memliki kepedulian dan perhatian yang tinggi terhadap pendidikan anaknya, sehingga hasil belajar yang dicapai siswa tinggi.

Indikator persepsi orang tua terhadap keberhasilan siswa masuk dalam kategori sangat tinggi, hal ini berarti orang tua siswa siswa kelas X dan XI IPS SMA Negeri 7 Surabaya sangat disiplin dalam membiasakan anaknya belajar dengan penuh berkosentrasi yaitu dengan mengkondisikan suasana yang tenang 
dan nyaman sehingga siswa menjadi lebih semangat, tekun dan rajin dalam belajar yang akhirnya nilai yang dicapai siswa tinggi.

Indikator dukungan orang tua masuk dalam kategori sangat tinggi, hal ini berarti siswa kelas X dan XI IPS SMA Negeri 7 Surabaya memiliki orang tua yang peduli dan perhatian terhadap pendidikan, sehingga siswa termotivasi untuk belajar guna mewujudkan cita-cita yang ingin dicapainya.

Pada variabel kedisiplinan untuk indikator menaati dan mematuhi tata tertib sekolah, masuk dalam kategori tinggi, hal ini berarti siswa kelas $\mathrm{X}$ dan XI IPS SMA Negeri 7 Surabaya memiliki kedisiplinan tinggi dalam mematuhi tata tertib sekolah, sehingga mereka tidak lagi melakukan pelanggaran yang berakibat dengan pemberian sanksi pada mereka atas pelanggaran tersebut.

Indikator masuk kelas tepat waktu, masuk dalam kategori tinggi, hal ini berarti siswa kelas $\mathrm{X}$ dan XI IPS SMA Negeri 7 Surabaya memiliki kedisiplinan tinggi dalam mematuhi tata tertib sekolah, sehingga pemberian sanksi atas pelanggaran yang dilakukan siswa menurun.

Indikator ketertiban diri saat belajar di kelas, masuk dalam kategori tinggi, hal ini berarti siswa kelas X dan XI IPS SMA Negeri 7 Surabaya memiliki kedisiplinan tinggi dalam belajar di kelas, sehingga tidak ada lagi siswa yang malas atau menunda menyelesaikan pekerjaan maupun tugas yang diberikan guru.

Indikator mengatur waktu belajar di rumah, masuk dalam kategori tinggi, hal ini berarti siswa kelas X dan XI IPS SMA Negeri 7 Surabaya memiliki kedisiplinan tinggi dalam belajar, sehingga dengan belajar teratur akan menjadi kebiasaan dan tidak lagi menjadi beban.

Indikator mengulang kembali pelajaran di rumah, masuk dalam kategori tinggi, hal ini berarti siswa kelas X dan XI IPS SMA Negeri 7 Surabaya memiliki kedisiplinan tinggi dalam belajar, dengan mempelajari materi pelajaran di rumah serta berusaha mencoba untuk mengerjakan soal-soal yang berkaitan dengan materi tersebut sehingga akan didapatkan hasil belajar yang baik pula.

Indikator mengerjakan tugas sekolah di rumah, masuk dalam kategori tinggi, hal ini berarti siswa kelas X dan XI IPS SMA Negeri 7 Surabaya memiliki kedisiplinan yang tinggi dalam mematuhi tata tertib sekolah, dalam hal mengerjakan PR maupun tugas yang diberikan guru.

Pada variabel motivasi belajar untuk indikator keinginan untuk berprestasi, masuk dalam kategori sangat tinggi, hal ini berarti siswa kelas $\mathrm{X}$ dan XI IPS SMA Negeri 7 Surabaya memiliki motivasi dari dalam dengan keinginan untuk berprestasi yang sangat tinggi sehingga mereka akan berusaha mewujudkan keinginan itu dengan semangat belajar yang sangat tinggi pula, siswa lebih rajin belajar untuk mencapai prestasi yang lebih baik.

Untuk indikator harapan untuk berhasil, masuk dalam kategori tinggi, hal ini berarti siswa kelas X dan XI IPS SMA Negeri 7 Surabaya memiliki motivasi yang tinggi untuk belajar ekonomi, baik belajar secara tekun, maupun berusaha bertanya terhadap apa yang mereka tidak mengerti atau ketahui.

Sedangkan indikator belajar dari kegagalan/ ketidakberdayaan, masuk dalam kategori tinggi, hal ini berarti siswa kelas X dan XI IPS SMA Negeri 7 Surabaya memiliki motivasi yang tinggi untuk belajar ekonomi, baik belajar secara tekun, maupun berusaha bertanya terhadap apa yang mereka tidak 
mengerti atau ketahui serta bila mendapatkan nilai jelek mereka akan berusaha memperbaikinya dengan belajar lebih giat.

Dari uraian hasil penelitian di atas dapat disimpulkan bahwa secara bersama-sama (simultan) lingkungan keluarga, kedisiplinan siswa, dan motivasi belajar berpengaruh signifikan terhadap hasil belajar ekonomi siswa di SMA Negeri 7 Surabaya.

Hal ini sesuai dengan kenyataannya bahwa apabila peran orang tua dalam lingkungan keluarga tinggi, kedisiplinan siswa tinggi dan didukung dengan motivasi belajar yang tinggi maka hasil belajar siswa tentunya akan meningkat.

Apabila dalam lingkungan keluarga mampu menciptakan suasana belajar yang nyaman dan tenang maka akan mempengaruhi kedisiplinan siswa dalam belajar baik di rumah maupun di sekolah serta didukung motivasi belajar yang tinggi tentunya akan berpengaruh terhadap hasil belajar siswa yaitu mendapatkan nilai tinggi selama pembelajaran ekonomi di SMA Negeri 7 Surabaya.

Hal tersebut didukung oleh temuan Sudjana (2004) yang menunjukkan bahwa hasil belajar merupakan hasil yang diperoleh siswa dari proses belajar mengajar yang nampak dalam bentuk pengukuran atau penilaian tingkah laku secara menyeluruh yang terdiri dari bidang kognitif (penguasaan pengetahuan), afektif (sikap) dan psikomotorik (ketrampilan) secara terpadu pada diri siswa dan dapat dicapai dengan kriteria tertentu. Hasil belajar dapat diketahui dengan pengukuran atau penilaian, penilaian ini dimaksudkan untuk mengetahui sejauhmana pemahaman atau penguasaan pengetahuan siswa setelah mengikuti proses pembelajaran.

Hal ini didukung oleh penelitian terdahulu yang memiliki relevansi dengan variabel hasil belajar yaitu: penelitian Khafid dan Suroso (2007) menunjukkan secara parsial lingkungan keluarga berpengaruh signifikan terhadap hasil belajar ekonomi, dan secara parsial disiplin belajar berpengaruh signifikan terhadap hasil belajar ekonomi, serta secara simultan lingkungan keluarga dan disiplin belajar berpengaruh signifikan terhadap hasil belajar ekonomi. Untuk lebih meningkatkan keabsahan penelitian ini maka perlu juga dilakukan penelitian dengan memakai model atau menggunakan metode ataupun strategi pembelajaran lain yang relevan sehingga dapat meningkatkan kemampuan hasil belajar siswa dan kemampuan siswa dalam berpikir secara kritis.

Penelitian Ketut Sudarma dan Eva M. Sakdiyah (2007) menunjukkan bahwa secara parsial motivasi berpengaruh positif dan signifikan terhadap prestasi belajar Akuntansi kelas XI IPS SMA Negeri I Tayu Pati, secara parsial disiplin berpengaruh positif dan signifikan terhadap prestasi belajar Akuntansi kelas XI IPS SMA Negeri I Tayu Pati, serta secara simultan motivasi dan disiplin berpengaruh positif dan signifikan terhadap prestasi belajar Akuntansi kelas XI IPS SMA Negeri I Tayu Pati.

Penelitian Rusmiasih (2013) menunjukkan bahwa variabel motivasi termasuk kategori cukup, kedisiplinan pada kategori tinggi dan hasil belajar ekonomi pada kategori baik. Berdasarkan analisis kuantitatif menunjukkan bahwa variabel motivasi secara parsial memberikan pengaruh yang positif dan signifikan terhadap hasil belajar ekonomi, variabel kedisiplinan secara parsial memberikan pengaruh yang positif dan signifikan terhadap hasil belajar 
ekonomi, variabel motivasi dan kedisiplinan secara simultan memberikan pengaruh yang positif dan signifikan terhadap hasil belajar ekonomi.

Dari hasil analisis data dan penjelasan di atas terbukti jika lingkungan keluarga, kedisiplinan siswa, dan motivasi belajar secara bersama-sama ada pengaruh yang signifikan terhadap hasil belajar siswa kelas X dan XI IPS di SMA Negeri 7 Surabaya.

\section{KESIMPULAN}

Berdasarkan hasil analisis regresi linier berganda dapat disimpulkan bahwa : Ada pengaruh signifikan dan positif lingkungan keluarga terhadap hasil belajar ekonomi siswa SMA Negeri 7 Surabaya. Hal ini berarti semakin baik kondisi dan perhatian serta dukungan orang tua akan diikuti dengan hasil belajar yang baik pula. Ada pengaruh signifikan dan positif kedisiplinan siswa terhadap hasil belajar ekonomi siswa SMA Negeri 7 Surabaya. Hal ini berarti semakin tinggi kedisiplinan yang dimiliki siswa maka akan berpengaruh terhadap peningkatan hasil belajar. Ada pengaruh signifikan dan positif motivasi belajar terhadap hasil belajar ekonomi siswa SMA Negeri 7 Surabaya. Hal ini berarti dengan motivasi belajar yang tinggi akan mendorong keinginan mereka untuk memiliki hasil belajar yang tinggi. Ada pengaruh signifikan dan positif lingkungan keluarga, kedisiplinan dan motivasi belajar secara bersamasama terhadap hasil belajar ekonomi siswa SMA Negeri 7 Surabaya. Hal ini berarti lingkungan keluarga yang mendukung diimbangi dengan kedisiplinan yang tinggi dan motivasi belajar yang tinggi akan meningkatkan hasil belajar siswa.

Peneliti merekomendasikan beberapa saran sebagai berikut : Pada variabel lingkungan keluarga indikator yang rendah adalah sikap positif orang tua, orang tua hendaknya mampu menciptakan lingkungan yang harmonis antara sesama anggota keluarga di rumah, sehingga dapat membuat anak merasa betah dan bisa konsentrasi dalam belajar di rumah sehingga dapat meningkatkan hasil belajar. Pada variabel kedisiplinan siswa indikator yang rendah adalah menaati dan mematuhi tata tertib sekolah, diharapkan sekolah terutama guru untuk lebih tegas dalam memberikan sanksi atas pelanggaran yang dilakukan siswa, sehingga siswa akan jera dan tidak melakukan pelanggaran lagi, hal ini untuk meminimalisisr terjadinya pelanggaran di sekolah. Bagi pihak sekolah disarankan dapat lebih meningkatkan suasana konduktif dan memaksimalkan keamanan dan kenyamanan lingkungan serta media dan sumber belajar yang tersedia di sekolah untuk meningkatkan proses belajar mengajar agar lebih efektif. Hal ini untuk membangkitkan dan meningkatkan motivasi belajar siswa sehingga dapat pula meningkatkan hasil belajar mereka.

Lingkungan keluarga, kedisiplinan siswa, dan motivasi belajar secara bersama-sama dapat mempengaruhi hasil belajar di SMA Negeri 7 Surabaya. Dari hasil penelitian ini masih banyak faktor-faktor lain yang mempengaruhi hasil belajar siswa sehingga perlu diadakan penelitian lanjutan dengan variabel lainnya untuk mengetahui faktor-faktor lain yang akan berpengaruh pada hasil belajar siswa. 


\section{DAFTAR RUJUKAN}

Abolarin, Elizabeth Ebun. 2014. " The Influence of Prenatal, Home and Environmental factors on Learning Outcomes of Pre-Primary School Children". IOSR Journal of Research \& Method in Education (IOSRJRME) Volume 4, Issue 6 Ver. III (Nov - Dec. 2014).

Andartari, dkk. 2013. "Pengaruh Kemampuan Intelektual (Iq) Dan Motivasi Belajar Terhadap Hasil Belajar Siswa Pada Mata Pelajaran Akuntansi Pada Sma Labschool Rawamangun”. Jurnal Pendidikan Ekonomi Dan Bisnis Vol.1 No. 1 Maret 2013. ISSN: 2302 - 2663

Awan, dkk. 2011. "A Study of Relationship between Achievement Motivation, Self Concept and Achievement in English and Mathematics at Secondary Level”. International Education Studies Vol. 4, No 3. 2011

Chou, Pao. 2012. "Effect of Student's self Directed Learning Diciplin on Online Learning Outcome : Two Exploratory Experiment in Electronic Engineering" Review of Educational research. Vol 71 No. 5, pp. 6-14.

Codjoe and Dalton. 2007. "The importance of home environment and parental encouragement in the acadenic achievement of African Canadian Youth". Canadian Journal Of Education.30,1.

Djaali. 2013. Psikologi Pendidikan. Jakarta : PT Bumi Aksara.

Djamarah, Syaiful Bahri. 2011. Psikologi Belajar. Jakarta: PT Rineka Cipta.

Fadillah, Nur. 2011. "Pengaruh Motivasi Belajar terhadap Prestasi Belajar pada Mata Diklat Mail Handling”. Jurnal Pendidikan Ekonomi. Volume 4 Nomor 2 Oktober 2011. PPI 29-137.

Hamalik, Oemar. 2011. Kurikulum dan Pembelajaran. Jakarta: PT Bumi Aksara.

Hasbullah. 2010. Dasar-dasar Imu Pendidikan. Jakarta : PT Raja Grafindo Persada.

Ketut Sudarma dan Eva M. Sakdiyah. 2007. "Pengaruh Motivasi, Disiplin, Dan Partisipasi Siswa Dalam Pembelajaran Terhadap Prestasi Belajar Akuntansi”. Jurnal Pendidikan Ekonomi Vol 2 No.2 Juli, 2007.

Khafid, Muhammad \& Suroso. 2007. "Pengaruh disiplin belajar dan lingkungan keluarga terhadap hasil belajar ekonomi” Fakultas Ekonomi : Universitas Negeri Semarang.

Lawrence. 2012. "Effect learning dicipline on academic achievement of standar student" Jurnal Education. Vol. 9 No. 7, January 2012. 00. 140150.

Mackay, Ross. 2005. "The Impact Of Family Structure And Family Change On Child Outcomes: A Personal Reading Of The Research Literature". Journal of New Zealand. Issue 24. March 2005. 
Mappeasse, Muh. Yusuf. 2009. "Pengaruh Cara dan Motivasi Belajar terhadap Hasil Belajar Programmable Logic Controller (PLC) Siswa Kelas III Jurusan Listrik SMK Negeri 5 Makassar”. Jurnal MedTek, Volume 1, Nomoer 2, Oktober 2009.

Munib, Achmad. (2005). Pengantar Ilmu Pendidikan. Semarang: UPT UNNES Press.

Moenir, Has. 2010. Manajemen Pelayanan Umum di Indonesia. Jakarta : Bumi Aksara.

Mohanraj, Rani and Latha. 2005. "Perceived family environment in relation to adjustment and academic Achievement". Journal of the Indian Academy of Applied Psychology. Vol 31. 2005.

Pasternak, Rachel. 2013. "Discipline, learning skills and academic achievement". Journal of Arts and Education Vol. 1(1), pp. 1-11, June 2013

Patricia Robledo-Ramón and Jesús-Nicasio García-Sánchez. 2012. “The Family Environment of Students With Learning Disabilities And $A D H D ”$. University of León. Spain.

Purnomowati, Riris. 2006. Pengaruh Disiplin Dan Motivasi Belajar Terhadap Prestasi Belajar Siswa Kelas X Smk Teuku Umar Semarang Tahun Ajaran 2005/2006. Skripsi. Universitas Negeri Semarang.

Rusmiasih. 2013. Pengaruh Motivasi dan Kedisiplinan Belajar terhadap Hasil Belajar Ekonomi Siswa Kelas XI IPS di SMAN 10 Purworejo. Jurnal Perndidikan Ekonomi. Vol 2. No. 3 Januari 2013. Pp. 10-18

Slameto. 2010. Belajar dan Faktor-faktor yang mempengaruhinya. Jakarta : Rineka Cipta.

Sudjana, Nana. 2004. Penilaian Hasil Proses Belajar Mengajar. Bandung: Rosadakarya.

Sugiyono. 2011. Metode Penelitian kuntitatif Kualitatif dan R\&D. Bandung: Alfabeta.

Sukawijaya, I Wayan. 2010. "Kontribusi Hasil Belajar Seni Rupa, Kedisiplinan Diri dan Motivasi Berprestasi terhadap Hasil Belajar Komputer Grafis Siswa Program Keahlian Multimedia SMK Negeri 2 Sukawati”. Tesis. Pascasarjana Universitas Ganesha Singaraja.

Theresia. L \& Tanwey. G.R. 2011. Penilaian Hasil Belajar pada Tingkat Satuan Pendidikan. Unesa Uneversity Press.

Tella, Adedeji. 2007. "The Impact of Motivation on Student's Academic Achievement and Learning Outcomes in Mathematics among Secondary School Students in Nigeria". Eurasia Journal of Mathematics, Science \& Technology Education. Vol 3 Nos 2, 2007. 
Tomo, J. 2008. Hubungan Antara Sikap, Motivasi, Disiplin Belajar dan Prestasi Belajar Mahasiswa D-II PGSD Prajabatan FKIP Universitas Pattimura. Tesis. Universitas Negeri Malang.

Tu’u, Tulus. 2004. "Peran Disiplin pada Perilaku dan Prestasi Siswa”. Jakarta: Grasindo.

Uno, Hamzah.2008. Teori Motivasi dan Pengukurannya. Bandung: Bumi Aksara.

Yudhawati, Ratna dan Danny Haryanto. 2011. “Teori-teori Dasar Psikologi Pendidikan”. Jakarta: PT. Prestasi Pustakaraya. 